\title{
The Proposal of West Java Export Coffee Distribution Model
}

\author{
${ }^{1}$ RAKHMAT CEHA, ${ }^{2}$ M. DZIKRON,${ }^{3}$ CHAZNIN R. MUHAMAD, \\ ${ }^{4}$ M. FARASH SYAHMI, ${ }^{5}$ SHINTHIA RIYANTO \\ 1,2,3Universitas Islam Bandung, Jl. Tamansari No.1, Indonesia, \\ 4,5SPD Global, Jl. Ir. H. Djuanda No. 284, Indonesia \\ email: ${ }^{1}$ rceha@yahoo.com; ${ }^{2}$ mdzikron@gmail.com, ${ }^{3}$ chaznin_crm@yahoo.co.id, \\ ${ }^{4}$ muhammadfarash1@gmail.com, ${ }^{5}$ shinthiariyanto@gmail.com
}

\begin{abstract}
Currently, West Java exports coffee through 3 companies, namely Sari Makmur Medan, Indokom Surabaya, and Deltamas Semarang. The long distribution chain causes low prices at farmers' level. If the coffee is exported directly, it is estimated to increase the selling price of coffee beans at farm level. The purpose of this study is to design a coffee distribution model, so that West Java can export directly to several destination countries by fulfilling the requirements of international trade. In designing the West Java coffee distribution model, four stages were conducted, namely mapping business processes, cluster division, optimization models, and location theory analysis. As the result, this research has produced two alternative proposals for the West Java coffee export distribution model. To test the feasibility of the proposed distribution model, Focus Group Discussion (FGD) has been carried out with stakeholders of coffee cooperatives, Gapoktan (farmer's association), coffee associations, and others.
\end{abstract}

Keywords: Coffee; West Java; Distribution

\section{Introduction}

The development of world coffee trade is dominated by supplies from African and South American countries. The main coffee commodities are Arabica coffee which reaches around $65 \%$ of the world coffee market, while Robusta coffee is around 35\%. Arabica coffee is supplied by many countries in South America, Africa and India, while Robusta is widely supplied from Vietnam and Indonesia (Suhartana \& Sumino, 2008).

Meanwhile, Indonesia has the potency to be a coffee producer and a large market as well. Referring to the FAO data in 2013, Indonesia was recorded as the third largest coffee producer in the world after Brazil and Vietnam. Although having large coffee production, Indonesia's export value of coffee was smaller compared to Brazil, Vietnam, and Colombia. In the world market, Indonesian coffee commodities are known as the specialty coffee through various coffee and civet coffee variants. There are several well-known
Arabica Coffee commodities from Indonesia, such as Lintong and Toraja coffee. Indonesia has a great opportunity to increase the coffee trade in the world by offering the unique taste and aroma of coffee (DJP, 2015).

Indonesian coffee export volume and value from 1998 to 2017 increased significantly, as shown in Figure 1. International Coffee Organization (ICO) data shows that world coffee consumption in 2016/2017 periods grew $1.9 \%$ from the previous period. The growth of global coffee consumption certainly has a positive impact for Indonesia as the world's second largest coffee exporter (Katadata, 2017).

Based on data from Badan Pusat Statistik (BPS/The Central Bureau of Statistic), national coffee exports in 2017 grew $12.56 \%$ to 464 thousand tons from the previous year. Similarly, the export value increased by $17.48 \%$ to US $\$ 1.18$ billion or around Rp.15.9 trillion. Figure 1 shows that Indonesia's largest coffee export was recorded in 2013, reaching

Received: 2019-02-08, Revised: 2019-03-06, Accepted: 2019-05-28

Print ISSN: 0215-8175; Online ISSN: 2303-2499. DOI: http://dx.doi.org/10.29313/mimbar.v35i1.4428

Accredited $\mathbf{S 2}$ based on the decree No.10/E/KPT/2019 until 2024. Indexed by DOAJ, Sinta, Garuda, Crossreff, Dimensions 
532 thousand tons. The United States (US) is the largest coffee market for Indonesia. No less than 63 thousand tons or $13 \%$ of the total national coffee exports sent to the US with a value of US \$256 million. The other main export destinations for Indonesian coffee are Malaysia, Germany, Italy, Russia, and Japan.

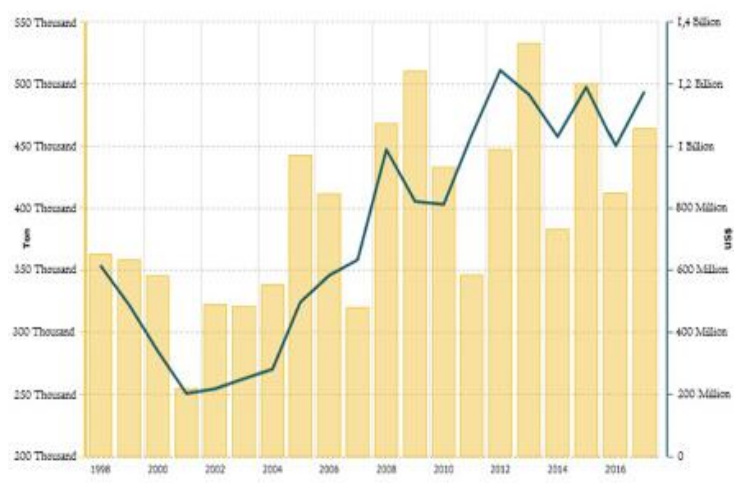

Figure 1. Indonesian Coffee Export Volume and Value (1998-2017)

Sources: (Katadata, 2017)

Based on the Permanent Figures of Indonesian Plantation Statistics (DJP, 2015), Indonesia's coffee production in 2014 was recorded at 643,857 tons. This production comes from $1,230,495$ ha of coffee plantation area where $96.19 \%$ is cultivated by individual (PR) while the rest is cultivated by large private-owned plantations (PBS) of $1.99 \%$ and large state-owned plantations (PBN) of $1,82 \%$. One of potential area for coffee production is West Java.

West Java is dominated by hilly and mountainous areas which are incidentally having fertile natural resources and a conducive living environment, both for the growth of various kinds of plants, from food crops, vegetables, horticulture, and plantation crops such as coffee. In the lowlands, there are many robusta coffee plants, while in the highlands it is dominated by arabica coffee plants.

Generally, the quality of West Java coffee of both robusta and arabica is classified as having a specific and unique flavor. To protect its special characteristic, Intellectual Property Rights (IPR) is gradually strived to obtain Geographical Indications (GI) protection. In 2013, after having GI protection, West Java coffee had already begun to be re-exported even though not too much. Several destination countries have been realized at this time; West Java coffee has been exported to Morocco, Belgium, Korea, Britain, Hong Kong, China, Germany, and other countries (Dinas Perkebunan Provinsi Jawa Barat/Plantation Office of West Java Province, 2016).

There are three exporter companies that usually handle export distribution in West Java. They are Sari Makmur located in Medan, Indokom in Surabaya, and Deltamas in Semarang. However, long coffee distribution chain causes low coffee price at farmers' level. If only West Java coffee product can be exported directly to destination countries, it could be expected to increase the coffee bean price for farmers and help them to survive.

Therefore, the objective of this study is to design a distribution model, so that West Java can export directly to several destination countries by concerning some aspects and requirements needed to do in exporting or international trade. The development of coffee supply chain distribution patterns in West Java can have an impact on increasing coffee sales revenue through the construction of coffee distribution centers for export gates from West Java and increasing coffee prices for farmers in West Java. In addition, by holding direct exports, it will be able to improve the atmosphere of global trade, create jobs, and also improve the performance of the West Java regional government.

\section{Research Methodology}

Supply chain is a physical network that supplies raw materials, produces goods, and delivers to end users on time and in a good quality. Meanwhile, supply chain management (SCM) is an integrated approach or method based on collaboration. SCM is oriented towards internal and external companies that relate to relationships with partners (Ceha, Dzikron, \& Riyanto, 2017). SCM describes the optimization discipline in distributing goods, services, or information from suppliers to customers. SCM shows various indicators such as demand forecasting, product availability, inventory management, and distribution (Palomino, Meza, Montes, \& Raffo, 2017). The integration of a supply chain not only focuses on tangible resources and assets, but also on intangibles such as knowledge. Knowledge is the only resource capable of offering a competitive advantage, continued growth, and prosperity for supply chain partners (Wu, 2008) technology adoption, supplier 


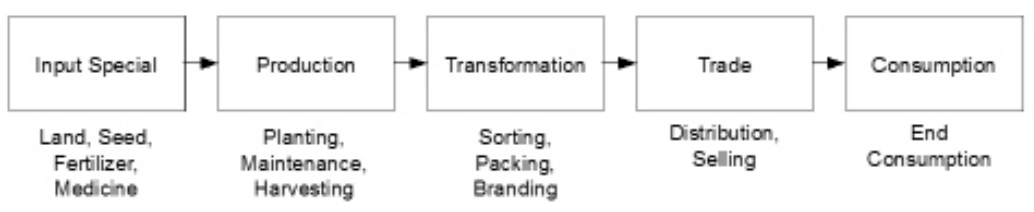

Stakeholders in value chain of the product/commodity

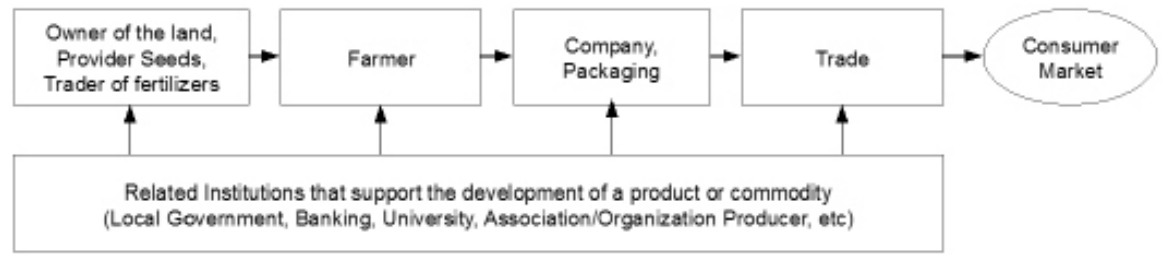

Figure 2 Value chain maps

Sources: (Arista, 2012)
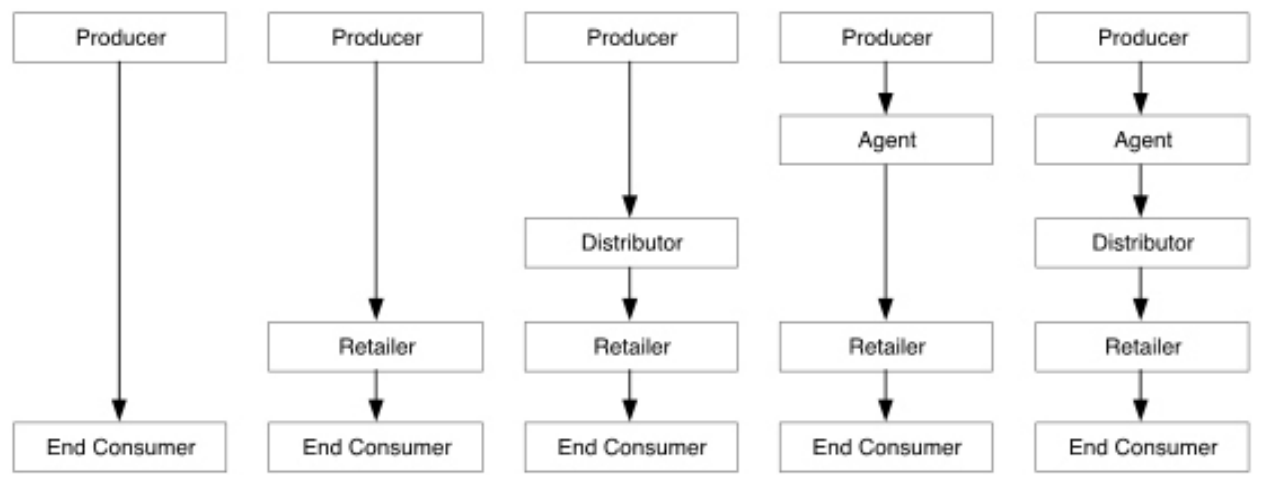

Figure 3. Types of Distribution Flow

relationship management and customer relationship management affect knowledge creation through socialization-externalization combination, internalization (SECI.

SCM according to the Council of Logistic Management (CLM) is planning, realizing, and controlling the efficiency and effectiveness of the flow and storage of goods, services, and related information to meet customer needs (Hayati, 2014). SCM is responsible for ensuring that a right product is in the right place, at the right time, in the right conditions, and with the right price for customer satisfaction. Activities included in SCM's performance are warehousing, packing, third party activities, inbound and outbound transportation, distribution, inventory control, purchasing, location planning and maintenance of production management, and customer satisfaction.

Figure 2 explains the value chain maps identify functions, operators, value chain supporting institutions, and relationships exist between value chain actors (Arista, 2012).

\section{Results And Discussion Distribution}

The distribution channel has an element in the distribution process which called intermediary. Intermediary means retailer, wholesaler, or large trader. Retailer is trader who sells products produced by producers directly to end users or consumers. The wholesaler is trader who sells products produced by producers with greater capacity than retailers. Large trader are trader who sells products produced by producers with large capacity (Imam, 2010).

Sales of consumer goods are intended for the consumer market, which are generally sold through intermediaries. This is intended to reduce the cost of achieving a wide spread market that producers cannot achieve one by one. In distributing consumer goods, there are five types of channels that can be used (Wulandari, 2014). Types of distribution flow are visualized in Figure 3. 
Producers - Consumers

The shortest and simplest form of distribution channel is the distribution channel from producer to consumer without using intermediaries. Producers can sell goods they produced by mail or directly visit consumers' house (from house to house). Therefore, this channel is called the direct distribution channel.

Producers - Retailers - Consumers

This channel is called a direct distribution channel. In this type, large retailers directly make purchases to producers. There are also some producers who set up retail stores so that they can directly serve consumers. But this final alternative is not commonly used.

Producers - Wholesalers - Retailers Consumers

This type of distribution is widely used by producers and called traditional distribution channels. Here, producers only serve large amounts of sales to large traders only, not selling to retailers. Purchases by retailers are served by wholesalers, and purchases by consumers are served by retailers only.

Producers - Agents - Retailers - Consumers Here, the producer chooses the agent as the distributor. He runs large trading activities in existing distribution channels. The sales target is mainly aimed at large retailers.

Producers - Agents - Wholesalers - Retailers - Consumers

In distribution channels, agent is often used as intermediaries to distribute their goods to large traders who then sell them to small shops. The agents in this distribution channel are mainly sales agents.

\section{The Stage of Coffee Distribution Model}

There are four stages in modeling the distribution of coffee exports in West Java. They are business process mapping, cluster division, optimization model, and location theory analysis.

\section{Business Process Mapping}

The business process is a set of instruments to organize the activity and to increase understanding of the interrelationship in the activity. Business processes are a set of activities in a business to produce products and services. IDEFO is a modelling function methodology to describe manufacturing functions which offers functional modelling languages for analysis, development, reengineering, and information system integration; business processes, or software engineering analysis Siegel in (Ceha et al., 2017).

\section{Cluster division with Clustering Method}

Clustering method can be applied in any field, but this technique is more familiar to be used in marketing field because one of the activities carried out in marketing is grouping, which is called market segmentation. The purpose of cluster analysis in marketing is to create market segments (segmenting the market), understand buyer behavior, recognize new product opportunities, and reduce data.

The agglomerative method starts with each object that forms its own cluster. Then two objects with the closest distance join. After that, the third object will join the existing cluster or with another object, then form a new cluster. This still calculates the proximity distance between objects. The process will continue until a cluster finally consists of all objects (Machfudhoh \& Wahyuningsih, 2013). One of the techniques in the Agglomerative Method is Single linkage (nearest neighbor methods). This method uses the minimum distance principle that begins with searching for two nearby objects and both form the first cluster. In the next step there are two possibilities: the third object will join the cluster that has been formed, or two other objects will form a new cluster. This process will continue until finally a single cluster is formed. In this method, the distance between clusters is defined as the closest distance between members. The steps in preparing the agglomerative single linkage method are as follows:

Find objects with a minimum distance.

$A$ and $B$ have the closest distance, that is 1.0, then objects $A$ and $B$ join into one cluster.

Calculate distance between cluster $A B$ and other objects.

$D(A B) C=\min \{d A C, d B C\}=d B C=3.0$

$D(A B) D=\min \{d A D, d B D\}=d A D=6.0$

$D(A B) E=\min \{d A E, d B E\}=d B E=7.0$

Thus, a new distance matrix is formed in figure 4 


\begin{tabular}{|c|c|c|c|c|}
\hline \hline & $\mathrm{AB}$ & $\mathrm{C}$ & $\mathrm{D}$ & $\mathrm{E}$ \\
\hline $\mathrm{AB}$ & 0.0 & 3.0 & 6.0 & 7.0 \\
\hline $\mathrm{C}$ & 3.0 & 0.0 & 4.0 & 6.0 \\
\hline $\mathrm{D}$ & 6.0 & 4.0 & 0.0 & 2.0 \\
\hline $\mathrm{E}$ & 7.0 & 6.0 & 2.0 & 0.0 \\
\hline \hline
\end{tabular}

Figure 4. New Distance Matrix

Find objects with the closest distance.

$D$ and $E$ have the closest distance which is 2.0, then the $D$ and $E$ objects are joined into one cluster.

Calculate distance between clusters and other objects.

$D(A B) C=3.0$

$D(A B)(D E)=\min \{d A D, d A E, d B D, d B E\}$

$=\mathrm{dAD}=6.0$

$D(D E) C=\min \{d C D, d C E\}=d C D=4.0$

Find the closest distance between clusters and the object, so that the $\mathrm{C}$ object is obtained to join the $A B$ cluster.

In the last step, the $A B C$ cluster joins the $D E$ and results a single cluster.

\section{Optimization Model with Logware}

The optimization model used in this paper is P-Median method. This method determines the distribution warehouse center of each cluster and also the center of the West Java export warehouse. The P-Median method can be used as a media to minimize the new problems in determining the center of the warehouse (Ceha, Dzikron, \& Muhammad, 2018) and (Ceha \& Dzikron, 2011).

Logware is a set of selected software to analyze various logistical problems and case studies. Logware is a program that provides various optimization modules for logistics and distribution activities (Firdaus, 2010). Router module is a module in Logware that provides optimization functions for routing planning and vehicle scheduling.

\section{Location Theory Analysis}

In relation to the location theory, several opinions are found. Location theories aim to explain why a firm chooses to locate at one location and not the others. In an optimization process that involves either maximizing profit or minimizing cost, a firm's ultimate location decision necessarily selects the best possible place among a given set of choices and constraints (Dubé, Brunelle, \&
Legros, 2013). One of them is according to Weber in (Sofa, 2008) that the selection of industrial location is based on the principle of cost minimization. Weber stated that the location of each industry depends on the minimum total cost of transportation and labor. A place with the minimum total transportation and labor are identical to the maximum level of profit. According to Weber, there are three factors that influence industrial location: transportation costs, labor wages, and the strength of agglomeration or deagglomeration. In explaining the relationship between transportation costs and raw materials, Weber uses the concept of location triangle to obtain the optimum location. To show whether the optimum location is closer to the location of raw material or market, Weber formulated a material index (IM), while labor costs as one of the factors that can affect industrial locations are explained by a closed curve in the form of a circle called isodapane (isodapan).

According to Liang and Wang in (Murti \& Aisyati, 2004), attributes of facility location selection in general can be grouped into three: critical attributes, objective attributes, and subjective attributes.

(Chen, 2001) states that there are five criteria that influence the decisionmaking process to determine the location of warehouse distribution (distribution center). These criteria are investment costs, expansion possibility, availability of acquirement material, availability of human resources, and closeness to demand market.

While (Ko, 2005) has five different criteria in determining the location of warehouse distribution center: the state of the population (population status), transportation conditions, market environments, location properties, and cost related factors.

Each criterion consists of several decision factors that influence the determination of the distribution warehouse location, which are shown in Table 1.

Table 1

The criteria and factors decision in determining distribution warehouse by Jesuk Ko

\begin{tabular}{lll}
\hline No. & Criteria & Decision factors \\
\hline 1 & $\begin{array}{l}\text { Population } \\
\text { status }\end{array}$ & $\begin{array}{l}\text { Population density } \\
\text { Income trends }\end{array}$
\end{tabular}



conditions

3

Location properties

5 Costrelated
factors

Market
environments

Attainment of favorable position Number of public transportations Number of pedestrians Traffic Network Degree of traffic congestion

Availability of public transportations

Number of Shops Number of competitors

Proximity to other markets

Size of facilities

Visibility of sites

Parking space

Proximity to car parking

Convenience /Easy access

Cost of land

Tax structure

Cost of maintenance and utilities

Legal considerations

Sources: (Ko, 2005)

The coffee supply chain in West Java has some different channels in each region. The availability of facilities and resources is one of the different factors in handling coffee distribution in an area. Farmers in Cianjur Regency, for example, receive machine assistance from the government but there is not enough clean water to do the pulper process; the coffee cherry harvest is also below the available engine capacity, so that farmers can only process coffee cherries to be sold to collectors.

The stages of coffee processing to end consumers are very diverse; it can be up to green beans, roast beans, or ground coffee. Coffee processing to green bean generally consists of 2 processes, namely dry and wet processes. However today, it has been developed into 4 types of processes which produce different flavors: honey process, semi wash process, full wash process, and natural process. Figure 5 shows an example of a wet coffee processing flow and Figure 6 shows an example of a dry process.

The results of the field activities consisted of several locations that had previously been assessed through secondary data collection. The location of the study was conducted in the city/region of West Java which has the potency of plantation land and coffee plantations. As for the research focus is the distribution channel and production data owned by farmers, cooperatives, associations, industrial entrepreneurs, government, and other relevant agencies. Currently, there are some types of coffee supply chain experienced by farmers in West Java. In taking data on field activities, sampling was carried out by several farmers or related parties to obtain the results of the supply chain flow that represented their respective regions. The results of observations of West Java coffee supply chain flow are shown in figure 7.

Based on the results of the mapping of West Java's coffee supply chain flow, it can be said that the current distribution system is very complicated. The problem that occurs at this time is the length of the distribution system which has an impact on the low income at the farm level.

\section{Proposal of West Java Coffee Distri- bution}

The improvement of coffee supply chain is expected to increase profits and improve the prosperity of farmers and other related parties more equally. It is realized through business process mapping, cluster determination, determination of distribution warehouse in each cluster and warehouse export center, and location theory analysis.

\section{Business Process Mapping Analysis}

In this study, the West Java coffee distribution business process has been successfully mapped in detail by (Ceha et al., 2018), but not included in this paper.

\section{Cluster Determination Analysis}

Based on the results of the calculation of P-Median Optimization with Logware, West Java region is divided into 4 clusters and the distribution center of each cluster is shown in Table 2. Meanwhile, the flow of coffee distribution between distribution warehouse center and coffee export warehouse is shown in Figure 8.

Warehouse location selection is 


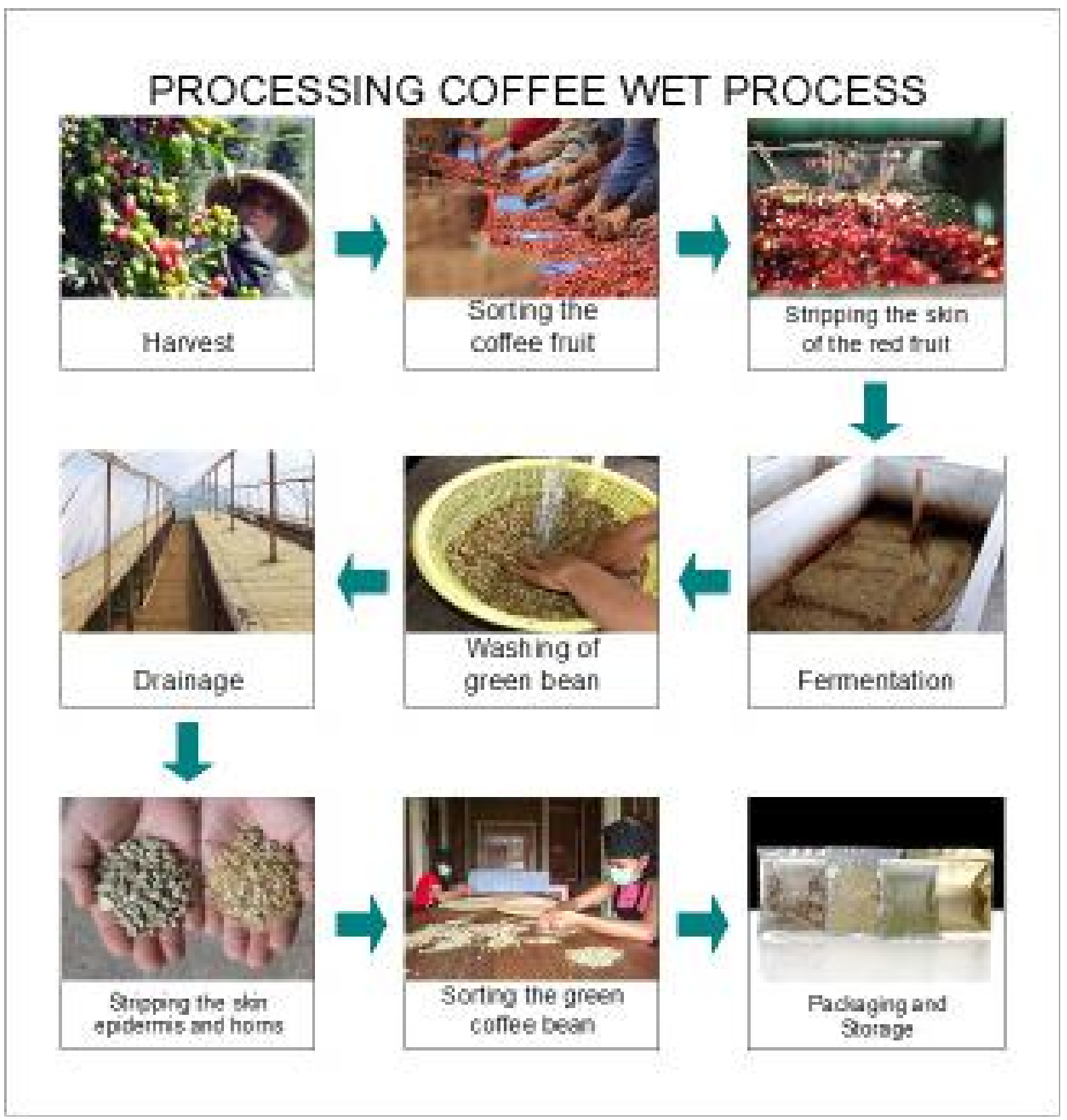

Figure 5. The process of wet coffee processing

determined based on the calculation of distance location, then calculated using the P-Median method to be chosen as the best warehouse location with optimal transportation costs and warehouse fixed costs.

\section{Analysis of Determination of Distri- bution Warehouses of each Cluster and Warehouse Export Center}

The selection of export warehouses is carried out in areas near the coast so that a port can be built and adjusted to the variables in location theory for industrial location selection. The choice for the construction of the West Java export warehouse location is Bekasi, Karawang, Subang, Indramayu, Regency/City of Cirebon.

The results of data processing using software Logware in determining the central location of distribution warehouses and export center warehouses are shown in Figure 9.

The calculation results using the P-Median method manually shows a very large cost in the construction of distribution warehouses and export warehouses. High costs are caused by long distance factors, the amount of production volume sent, and vehicle rental. In addition, there are also an increase of warehouse fixed costs. The total 


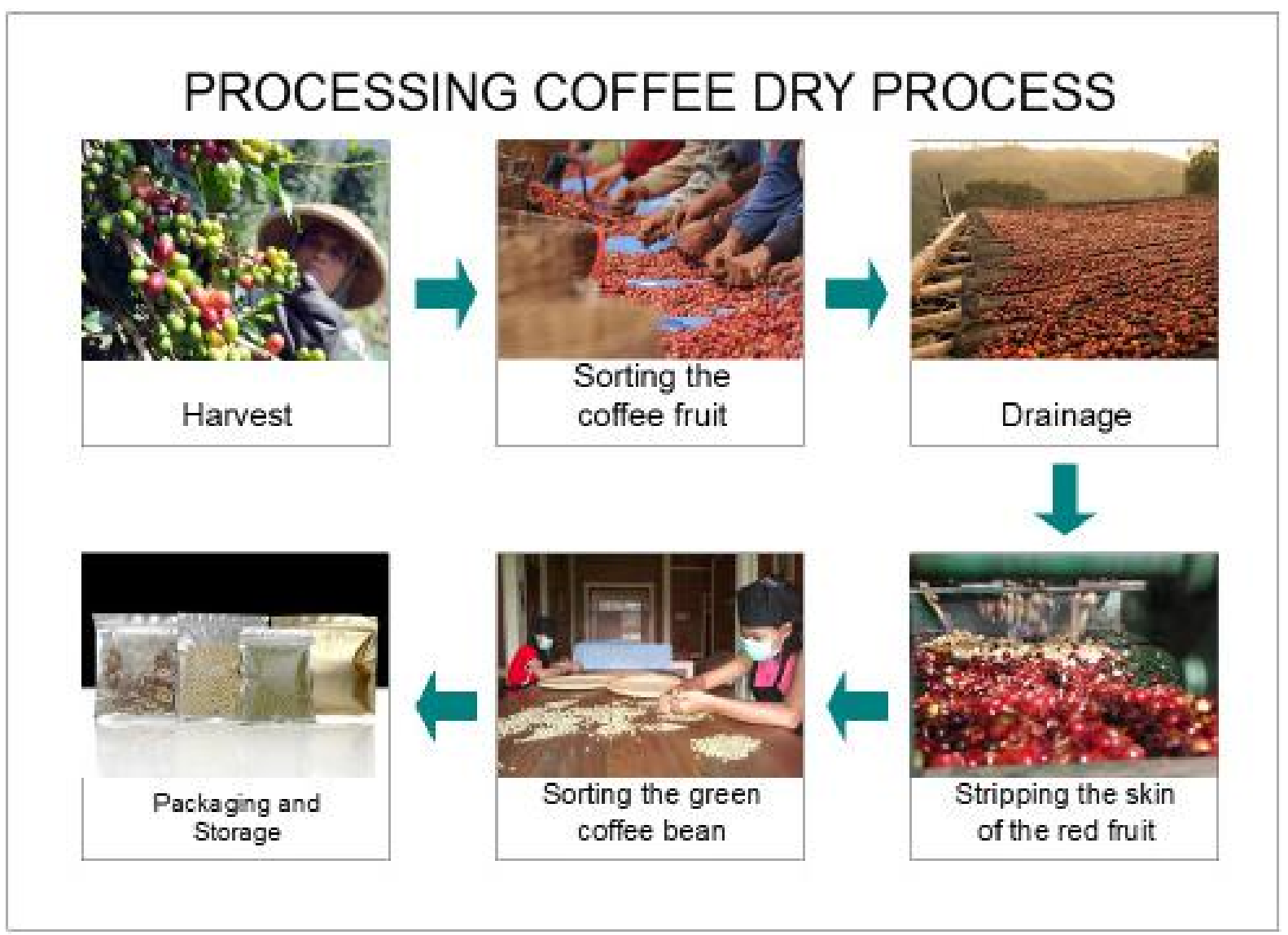

Figure 6. The process of dry coffee processing

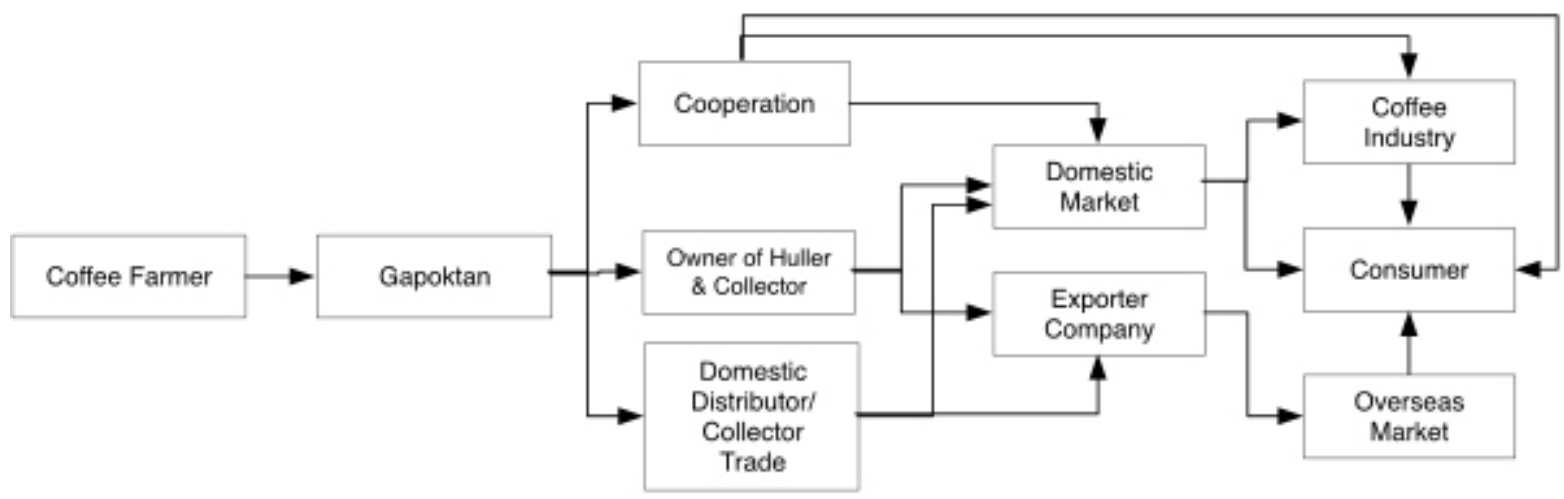

Figure 7. The existing West Java coffee supply chain flow

cost is the total cost during the coffee harvest season in one year.

\section{Analysis of Location Theory of Ware- house Distribution Center}

Based on the results of the Logware software testing, it was found that the optimal location to be used as a warehouse center in each cluster was Bogor Regency, West Bandung Regency, Kuningan Regency, and Tasikmalaya Regency. In this location theory, analysis of 5 variables will be conducted in selected locations. Table 3 and 4 show factors influenced in warehouse determination of each cluster and variables which based on factor classification.

\section{Model of West Java Export Coffee Distribution}

As an effort to improve the prosperity of coffee farmers and other related parties, the improvement of coffee supply chain through the development of coffee trade system by way of direct export from West Java is 
Table 2

Data Recapitulation of Total Production in Each Cluster

\begin{tabular}{|c|c|c|c|}
\hline No. & Clusters & Cities/Regions & Warehouse distribution center \\
\hline \multirow[t]{4}{*}{1.} & Cluster I & Sukabumi Regency & Bogor Regency \\
\hline & & Bogor Regency & \\
\hline & & Bekasi City & \\
\hline & & Karawang Regency & \\
\hline \multirow[t]{4}{*}{2.} & Cluster II & Cianjur Regency & West Bandung Regency \\
\hline & & Purwakarta Regency & \\
\hline & & West Bandung Regency & \\
\hline & & Bandung Regency & \\
\hline \multirow[t]{4}{*}{3.} & Cluster III & Subang Regency & Kuningan Regency \\
\hline & & Sumedang Regency & \\
\hline & & Majalengka Regency & \\
\hline & & Kuningan Regency & \\
\hline \multirow[t]{6}{*}{4.} & Cluster IV & Garut Regency & Tasikmalaya Regency \\
\hline & & Tasikmalaya Regency & \\
\hline & & Tasikmalaya City & \\
\hline & & Pangandaran Regency & \\
\hline & & Ciamis City & \\
\hline & & Banjar City & \\
\hline
\end{tabular}

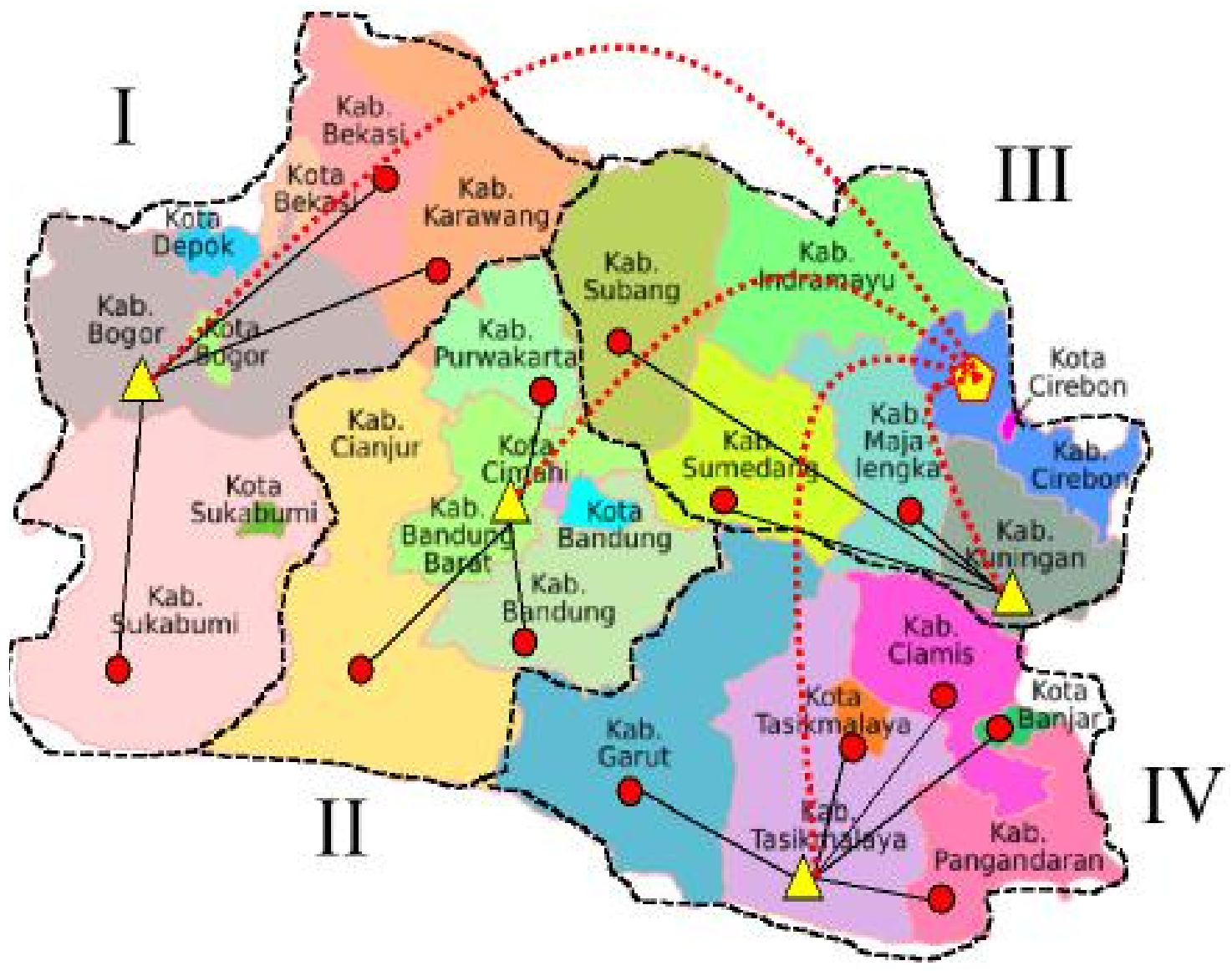

Description: Kab=Regency, Kota=City

Figure 8. The flow of coffee distribution between the distribution warehouse center and the coffee export warehouse West Java 
Coffee Producing City / Regency

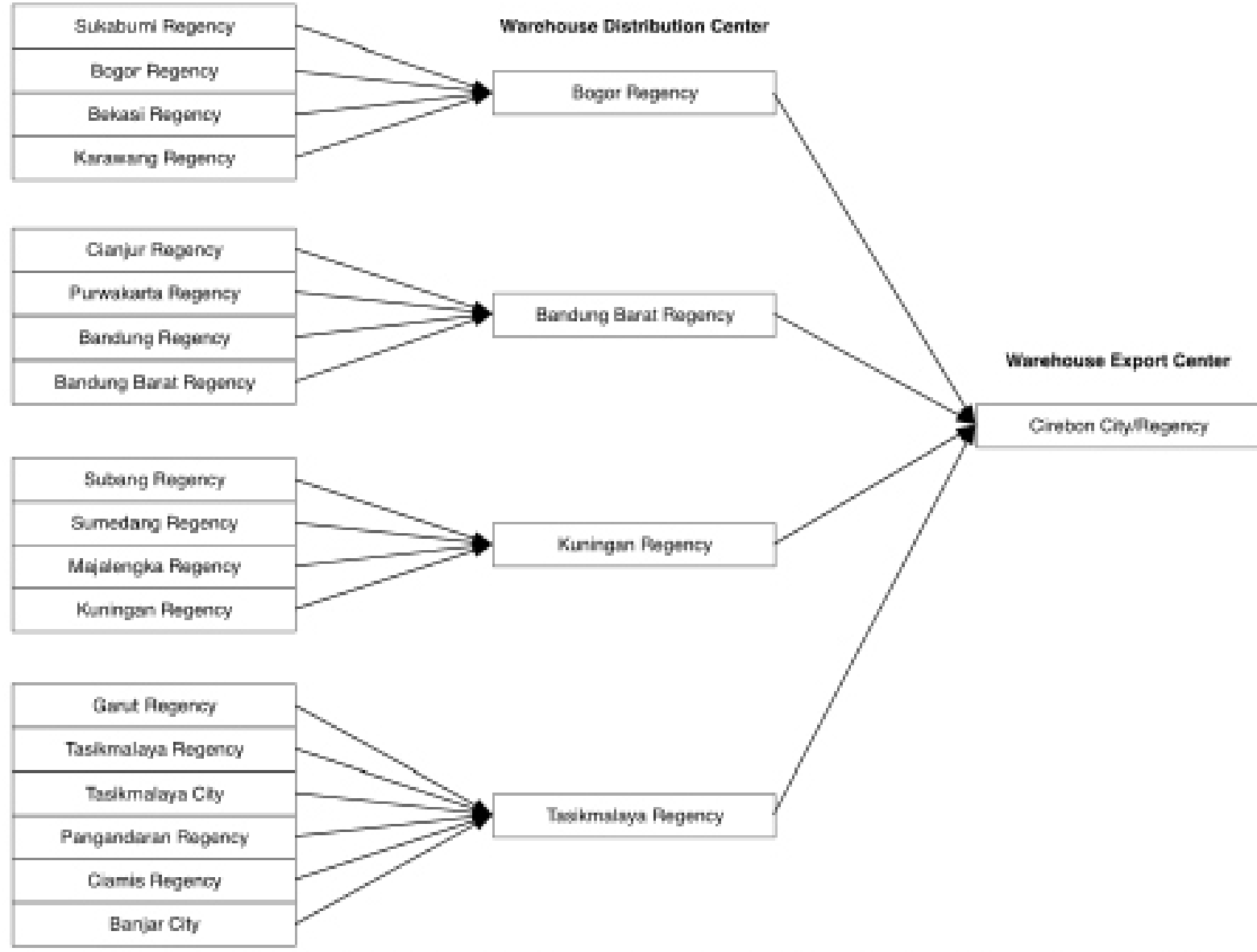

Figure 9. Selected Location of Distribution warehouse center and Export warehouse center

being proposed. That effort can be realized by coordinating the relevant parties such as farmers, gapoktan (a group of agribusiness farmers), cooperatives, exporters, hotel owners, restaurants, supermarkets, coffee industry, and government. This study found two proposals of West Java export coffee distribution models: The first one is Local Distribution and the second one is International Distribution.

\section{Proposal I: Local Distribution}

The coffee supply chain involves farmers, gapoktan, cooperatives, distributors, and consumers. Generally, the marketed coffee at farmer level is coffee beans. Figure 10 shows the coffee distribution pattern which is proposed in coffee distribution and marketing system in West Java. A short marketing pattern can be profitable for farmers since the shorter the trading system chain, the greater the margin received by farmers.

The coffee supply chains from the producer to the consumer level are:
Grade A Coffee

Farmers - Gapoktan - Cooperatives Hotels, Restaurant, Café, Coffee Shop, Retails, Consumer

\section{Grade B Coffee}

Farmers - Gapoktan - Cooperatives Supermarket/distributors - Consumer Grade C Coffee

Farmers - Gapoktan - Cooperatives Supermarket/distributors - Consumer Farmers - Gapoktan - Cooperatives - Coffee Industry (Manufacture) Supermarket/distributors - Consumer Farmers - Gapoktan - Cooperative - Coffee Industry (Manufacture) - Consumer

In the first proposal, cooperatives play an important role because it determines the quality of coffee and a higher selling price in accordance with the quality of the coffee cherry seeds offered, as well as maintaining the stability of coffee's price on the market. Hence, the quality of coffee that will be distributed to the next distribution chain has appropriate grade and price. 
Table 3

Factors Influenced in Determining the Warehouse of Each Cluster

\begin{tabular}{|c|c|c|}
\hline Sources & Factors & Factors classification \\
\hline $\begin{array}{l}\text { Study and location theory } \\
\text { (Smith, Weber, Losch, } \\
\text { Isard, Richardson, Alfred } \\
\text { in (Ceha et al., 2017)) }\end{array}$ & $\begin{array}{l}\text { - Industrial location } \\
\text { - Transportation cost } \\
\text { - Labor wages } \\
\text { - Agglomeration } \\
\text { - Production Amount } \\
\text { - Availability of raw materials }\end{array}$ & $\begin{array}{l}\text { Influencing factors in warehouse } \\
\text { selection location are classified } \\
\text { into } 5 \text { factors: } \\
\text { - Distance } \\
\text { - Transportation } \\
\text { - Facilities and infrastructure }\end{array}$ \\
\hline $\begin{array}{l}\text { Liang \& Wang (1991 in } \\
\text { (Ceha et al., 2017)) }\end{array}$ & $\begin{array}{l}\text { - Critical Attribute } \\
\text { - Objective Attribute } \\
\text { - Subjektif Attribute }\end{array}$ & - Raw Material \\
\hline $\begin{array}{l}\text { ChenTung Chen (Chen, } \\
\text { 2001) }\end{array}$ & $\begin{array}{l}\text { - Investment cost } \\
\text { - expansion possibility } \\
\text { - availability of acquirement } \\
\text { - } \text { material } \\
\text { - Closeness to demand market }\end{array}$ & \\
\hline Jesuk Ko (Ko, 2005) & $\begin{array}{l}\text { - Population status } \\
\text { - Transportation condition } \\
\text { - Market environment } \\
\text { - Location property } \\
\text { - Cost related factor }\end{array}$ & \\
\hline
\end{tabular}

Table 4

Variables based on Factors Classification

\begin{tabular}{|c|c|c|}
\hline No. & Variables & Sub Variables \\
\hline \multirow[t]{3}{*}{1} & Distance & Distance to the market \\
\hline & & Distance to the residence \\
\hline & & Distance to raw material sources \\
\hline \multirow[t]{3}{*}{2} & Transportation & Road access \\
\hline & & Public transportation \\
\hline & & Transportation cost \\
\hline \multirow[t]{3}{*}{3} & Facility and infrastructure & Electricity \\
\hline & & Water network \\
\hline & & Phone network \\
\hline 4 & Human Resources & Availability of human resources \\
\hline \multirow[t]{2}{*}{5} & Raw material & Quantity of Cherry coffee \\
\hline & & Continuity of Cherry coffee \\
\hline
\end{tabular}

\section{Proposal II:}

\section{International Distribution}

In the coffee supply chain Proposal II shown in figure 11, Gapoktan and Cooperatives sorted as in Proposal I. The cooperative only sends Grade A coffee beans to the Distribution Warehouse Center to be sent to the Export Warehouse Center (Exporter). Each warehouse cluster center has an international standard sorting machine, therefore, the implementation of sorting Grade A coffee beans from cooperatives will be filtered properly according to export standards. The Export Warehouse Center will gather the final sort of coffee beans that are ready to be sent/being exported. The cluster system is easier for farmers in West Java who plan to take part in exporting coffee beans, which at the end will create a more equally prosperity. 


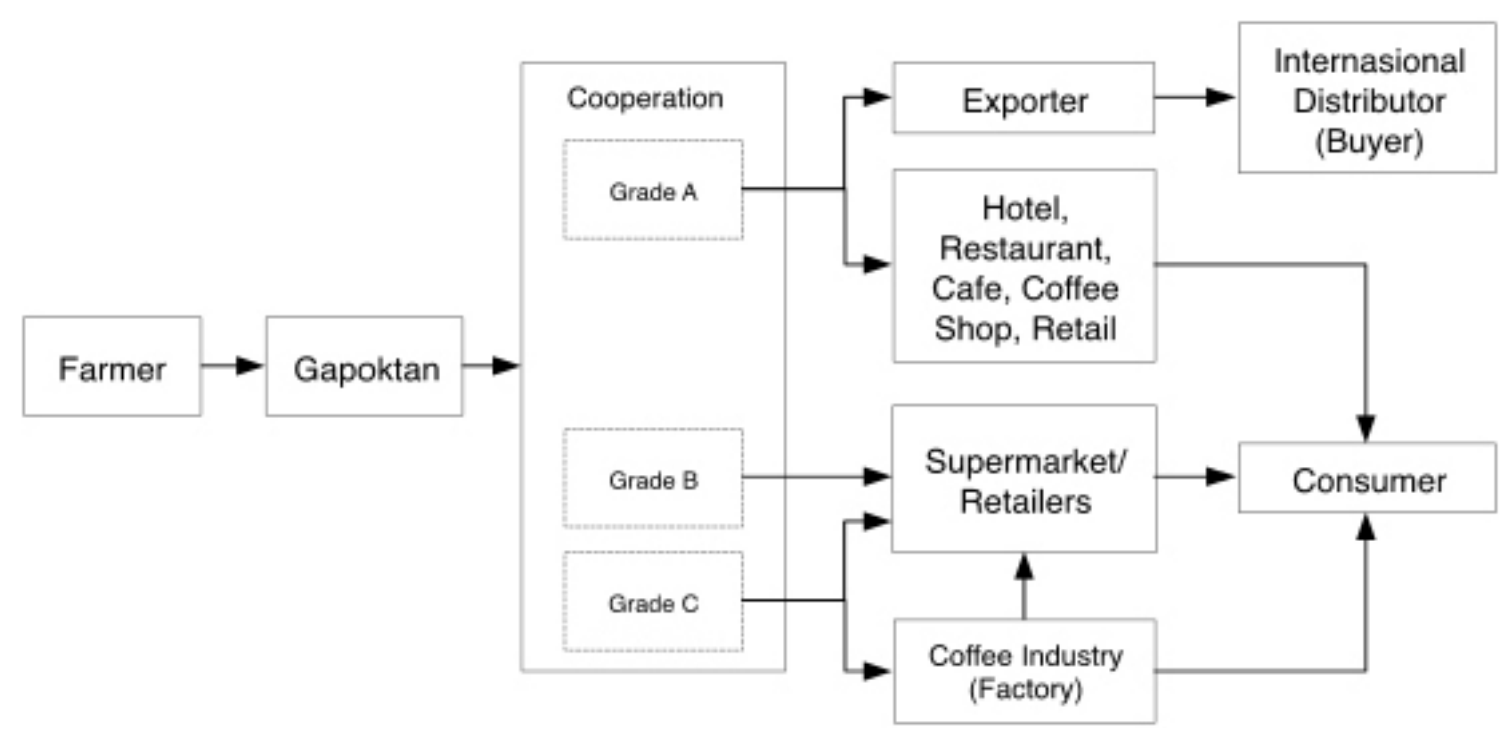

Figure 10. Alternative I : Proposal of coffee distribution

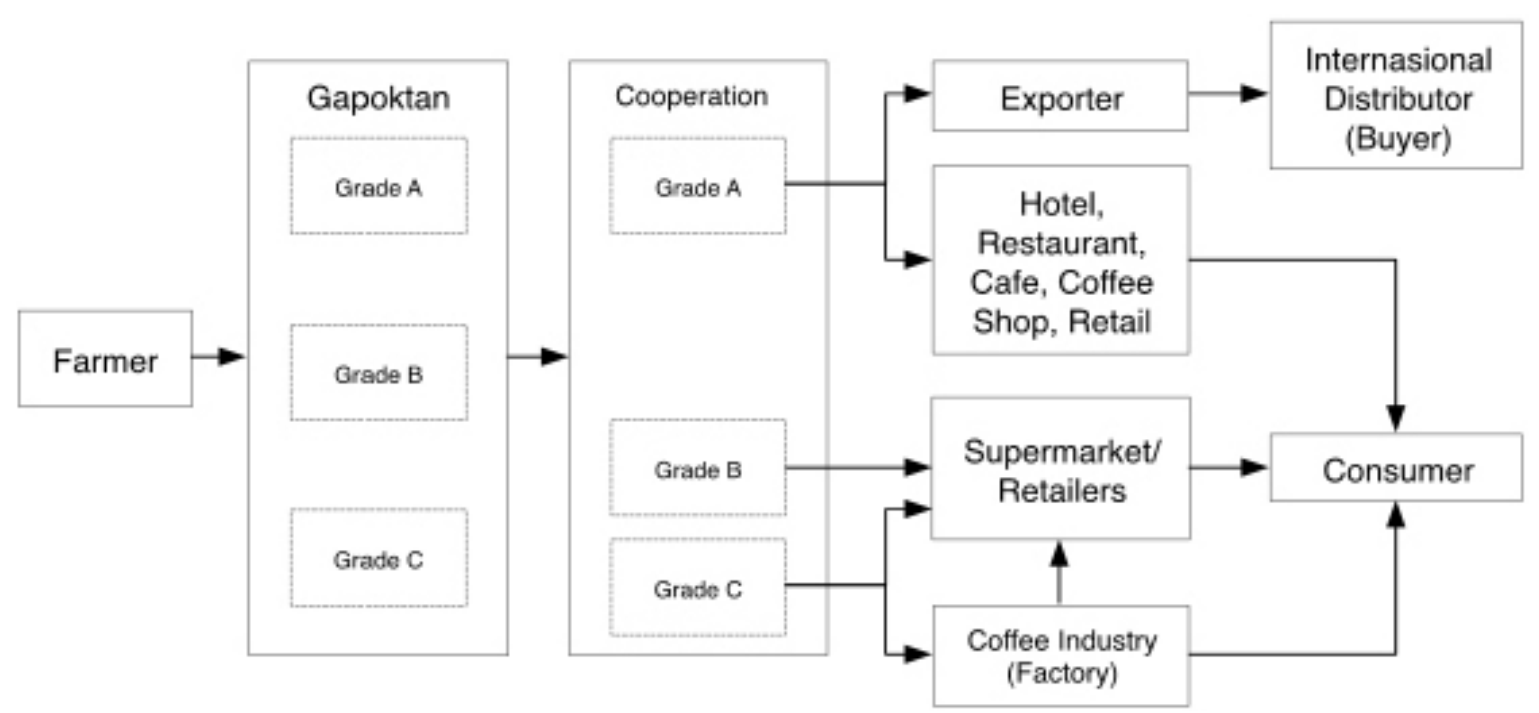

Figure 11 Alternative II: Proposal of coffee distribution

The results of Proposal I and II have cut the distribution channels which are considered unnecessary such as when the cooperatives, huller owners, and domestic distributors send coffee to the exporter outside West Java which only waste their time and money. Therefore, the researcher proposes to change distribution channels to be more optimal.

The duties, functions, and responsibilities of each party are shown in Table 5 .

\section{Conclusions}

In solving the problem of coffee distribution channels in West Java, a distribution path analysis was carried out, then determined the clusters and divided them into 4 parts. Each cluster has a representative as a distribution warehouse center, and from all regions in West Java, one location is chosen as an export gate. The location determination is using the Optimization Model (P-Median Method) in which the result had been considered its volume and cost of transportation. In addition to software testing, location theory analysis was carried out from each selected region.

In an effort to improve the prosperity of coffee farmers in West Java, local distribution and international distribution model was proposed. The proposal of local distribution models is considered as the most appropriate to the duties and responsibilities of each stakeholder so that there is no waste of time and costs. Whereas, the international distribution model shows the flow of coffee supply chains that are exported directly from West Java in order to improve the regional 
Table 5

Duties, Functions, and Responsibilities of each party

\begin{tabular}{|c|c|c|}
\hline No. & Unit & Duties, functions, and responsibilities \\
\hline 1. & Farmer & $\begin{array}{l}\text { - Planting, treating the coffee trees until harvesting } \\
\text { - Maintaining the quality of coffee cherry seeds } \\
\text { - Producing the best coffee cherry seeds to be processed at the } \\
\text { next stage. }\end{array}$ \\
\hline 2. & Gapoktan & $\begin{array}{l}\text { - Working with fellow farmers in collecting coffee cherry seeds } \\
\text { - Selling cherry coffee seeds picked directly from the garden } \\
\text { - Ensuring that the quality of cherry coffee beans are of the } \\
\text { appropriate grade }\end{array}$ \\
\hline 3. & Cooperative & $\begin{array}{l}\text { - Maintaining the stability of coffee prices at the farm level } \\
\text { - Giving the best service to farmers and the next distribution } \\
\text { chain } \\
\text { - Producing coffee beans, both green bean and roast bean to be } \\
\text { sold, and then processed in the next stage. } \\
\text { - Ensuring that the quality of cherry coffee beans are in an } \\
\text { - Fpropriate grade } \\
\text { - Postering gapoktan in producing good coffee } \\
\text { - Providing routine guidance and education related to coffee } \\
\text { Being an intermediary between government and farmers }\end{array}$ \\
\hline 4. & Exporter & $\begin{array}{l}\text { - Supplying the needs of the world market for coffee demand } \\
\text { - Collecting the best quality coffee beans } \\
\text { - Producing the best quality coffee in accordance to the standard } \\
\text { coffee requested } \\
\text { - Ensuring the availability of coffee and keeping the coffee in } \\
\text { good condition }\end{array}$ \\
\hline 5. & $\begin{array}{l}\text { Hotel, Restaurant, Cafe, } \\
\text { Coffee Shop, Retail }\end{array}$ & $\begin{array}{l}\text { - Level III distribution chain that sells coffee directly to consumers } \\
\text { in the form of coffee beans and ground coffee }\end{array}$ \\
\hline 6. & $\begin{array}{l}\text { Supermarket } \\
\text { Distributor }\end{array}$ & $\begin{array}{l}\text { - Market ready-to-consume coffee in packaging form to } \\
\text { consumers }\end{array}$ \\
\hline 7. & $\begin{array}{l}\text { Coffee Industry } \\
\text { (Manufacture) }\end{array}$ & $\begin{array}{l}\text { - Processing coffee beans into ground coffee for resale in } \\
\text { packaged coffee } \\
\text { - Market the processed coffee / ground coffee in domestic market }\end{array}$ \\
\hline
\end{tabular}

economy and the people of West Java. Besides that, the existence of export center in West Java can have an impact on improving human resource skills, opening up new jobs, and increasing the motivation to hold business both in local and global.

\section{References}

Arista, Y. (2012). Pengantar Teknik Industri. Retrieved from SlideShare website: https:// www.slideshare.net/yopyaristakuding/ ppt-pengantar-teknik-industri

Ceha, R., \& Dzikron, A. M. (2011). Model Sister Village dan Logistik untuk Mitigasi Bencana. Prosiding SNaPP Sains, Teknologi, Dan Kesehatan, 2(1), 149-156.

Ceha, R., Dzikron, A. M., \& Muhammad, C. R. (2018). Pengembangan Model Rantai Pasok Kopi untuk Meningkatkan Pendapatan dan Kesejahteraan Petani di Jawa Barat.
Ceha, R., Dzikron, A. M., \& Riyanto, S. (2017). Pendahuluan Perkembangan perdagangan kopi dunia didominasi oleh pasokan dari negara-negara Afrika dan Amerika Selatan - Komoditas kopi terutama adalah jenis Kopi Arabika yang mencapai sekitar 65 $\%$ dari pasar kopi dunia, sementara kopi Robusta sekitar 35. Prosiding SNaPP Sains Dan Teknologi, 7(2), 355-362.

Chen, C. T. (2001). A fuzzy approach to select the location of the distribution center. Elsevier Journal, 118(1), 65-73.

Dinas Perkebunan Provinsi Jawa Barat. (2016). Mengungkap Kopi Jawa Barat yang kembali jadi Idola Pasar Dunia.

DJP. (2015). Statistik Perkebunan Indonesia: Kopi 2014-2016. In Direktorat Jenderal Perkebunan Dept. Pertanian.

Dubé, J., Brunelle, C., \& Legros, D. (2013). Location Theories and Business Location Decision: A Micro-Spatial Investigation of a Area in Canada. Social Work Approaches 
in Health and Mental Health from Around the Globe, (January), 1-6. https://doi. org/I0.1300/J200v2n02_01

Firdaus, M. (2010). Manajemen Agribisnis. Jakarta: Bumi Aksara.

Hayati, E. N. (2014). Supply Chain Management (SCM) Dan Logistic Management. Jurnal Ilmiah Dinamika Teknik, 8(1), 25-34.

Imam, S. (2010). Bisnis Modern. Yogyakarta: Graha Ilmu.

Katadata. (2017). Berapa Ekspor Kopi Indonesia? Retrieved from https://databoks.katadata.co.id/ datapublish/2018/03/24/berapa-eksporkopi-indonesia

Ko, J. (2005). Solving a Distribution Facility Location Problem Using an Analytical Hierarchy Process Approach. Department of Industrial and Information Engineering. Gwangju University.

Machfudhoh, S., \& Wahyuningsih, N. (2013). Analisis Cluster Kabupaten / Kota Berdasarkan Pertumbuhan Ekonomi Jawa Timur. Sains Dan Seni Pomits, 2(1), 1-8. Murti, S. J., \& Aisyati, A. (2004). Penentuan
Jumlah dan Lokasi Gudang Yang Optimal Dengan Menggunakan Metode Cluster. 3 (1), 1-8.

Palomino, E. R., Meza, S. H., Montes, D. R., \& Raffo, F. S. (2017). Organic Coffee Supply Chain Management in the San Martin Region of Peru. International Journal of Innovation, Management and Technology, 8(1), 9-16. https://doi.org/10.18178/ ijimt.2017.8.1.694.

Sofa, H. (2008). Teori Lokasi. Retrieved from https://massofa.wordpress. com/2008/03/08/teori-lokasi.

Suhartana, N., \& Sumino. (2008). Menuju Pemasaran Kopi Spesial: Studi Kasus Pemasaran di 4 Sentra Produksi Kopi.

Wu, C. (2008). Knowledge creation in a supply chain. Supply Chain Management, 13(3), 241-250. https://doi. org/10.1108/13598540810871280.

Wulandari, D. (2014). Mengelola Saluran Distribusi. Retrieved from https://www. slideshare.net/desyaisyahwulandari/ mengelola-saluran-distribusislide?next_ slideshow $=1$. 